\title{
Thoughts and Practices on Public Policy Making and Accountability in Era of Khulafa Rosyidin's Government as a Concept, Theory and Model of Public Administration
}

\author{
Tjahjo Suprajogo \\ Faculty of Government Politics, \\ Institut Pemerintahan Dalam Negeri \\ Jatinangor, Indonesia \\ tjahjosuprajogo@yahoo.com
}

\author{
Suryadi \\ Faculty of Administration Sciences, \\ Universitas Brawijaya \\ Malang, Indonesia \\ suryadi@gmail.com
}

\begin{abstract}
There is theoretical and conceptual crisis and empirical problems of the modern public administration especially in the public policy making and accountability that represented by Old Public Administration (OPA), New Public Administration (NPA) and the New Public servce (NPS) paradigm and the New Public Management (NPM) as a very dominant and hegemonic paradigm today. The main aim of research is to explore their public policy making and accountability and formulate them theoretically as a concept, theory and model of modern public administration. The study using library research methods with critical history approach. The main sources are using Arabic literatures. The result of study are participative model of policy making, democratic and trancendental accountability.

Keyword: Khulafa Rosyidin, public policy making, public accountability
\end{abstract}

\section{INTRODUCTION}

Followed from the growth and development of the modern public administration since its inception as a study or scientific discipline both theory and practice has experienced various serious dynamics. Starting from the issue of identity crisis, problem identification, either in the form of understanding, concepts and principles are universal from the public administration, status as a discipline that can be called unique, but at the same time find it difficult to demonstrate or prove the distinctiveness of the public administration itself [1].

Theoretically and practically, paradigms that developed in the science of public administration, either Old Public Administration (OPA), New Public Administration (NPA), the New Public Management (NPM) and the New Public Service (NPS) each have several shortcoming besides the advantanges in the realm of policy making and public accountability. It has become the real phenomena that is happening in almost all countries on the policy-making and public accountability that there can not be separated from the global economic and political scenario today.

Strengthening neo-global capitalism has brought and led direction changes of bureaucracy from the state oriented to the free market mechanism (market oriented). Bureaucratic change is not only including policies sponsored by states such as deregulation, privatization and liberalization affecting the functional scope of administrative system, but also encompass restructuring and reorientation of the whole public bureaucracy into an market-friendly institution based on the principles such as managerialism, values for money, customerorientedness, a public-private partnership and resultsoriented management [2].

The market biased policies worrying because of the perceived conflict with democratic institutions. Also, it because of diminishing public support for the policies that have negative effects on a variety of state-run social programs [3]. In many countries, reform of market-bias under programs of stabilization and structural adjustment, which led to the elimination of food subsidies, cutbacks in social services, and the redistribution of income to the poor, has been increasing unrest and violence [3].

Departing from the conceptual theoretical crisis and current empirical problem in policy-making and public accountability is presented by some paradigm of public administration above, the researcher tried thrusting another discourse i.e. thought and practice in policy making and public accountability of Khilafat Rosyidin government in 632 -656 AD (1035 Hijriyyah) as concepts, theories and models in the science of public administration that already exists. 
Selection of the discourse is based on several reasons, among others, as follows:

First, historical approach that used in this study has proved the existence of the thinking and practice of governance in the era of KhilafatRosyidin can be constructed into concepts and theories of the state administration, especially regarding policy making and public accountability.

Secondly, the thesis put forward by Robert N. Bellah (1976) which states that the governance era of Khilafat Rosyidin "very modern" to the circumstances of their period [4]. Exploration of thought and practices regarding policy making and public accountability in the Khilafat Rosyidin government. Contribution to the thinking and practice on policy making and public accountability of Khilafat Rosyidin government on concepts, theories and models into the science of public administration that already exists.

\section{METHOD OF RESEARCH}

This study used a qualitative research method i.e. library research using critical historiy approach. As the main source and support of data, researcher using a classical Arabic history literature especially Taarikh al Umaamwa al Mulkby Ibn Jarir Tabari (838-923 AD), al Bidayah wa an Nihaayah by Ibn Kathir (1301-1372 AD), Tabaqat al Kubra by Ibn Sa'd (784-845 AD) and recent historical books of the four Chaliphs especially by Shallabi (1963), considering the data estuary authenticity on thinking and practice of Khilafat Rosyidin government. Also supported by the results of the study of politics and government from Islamic jurists (fuqaha) and other scientists, both in classical such as al Ahkaam al Sulthoniyyah by al Mawardi (975-1058 AD) and Abu Ya'la (990-1066 AD) and modern books in Indonesian, Arabic and English such as Fiqh Siyasah : Kontektualisasi Doktrin Politik Islam by Iqbal (2001) and an Nazhaariyyah al Siyaasah al Islamiyyah by Rais (1953).

\section{RESULTS AND DISCUSSION}

Based on the available historical report regarding the governance of Khilafat Rosyidin, researcher can group the several important components that assumed the position as actors and institutions in policymaking and public accountability during the period of Khilafat Rosyidin consisting the Caliph with his authority and responsibility, Katib (Secretary), Ahlu Syuura/ Consultative Assembly, Wazir (Maid/Minister), Qadhi (Judge), Wali/Amir (Governor) and 'Amil (Regent/Mayor) and the community.
Compared with the concepts and theories of Trias Politica, in which power is divided into 3 (three) branches, namely the legislative, executive and judicial branches of government [5], the third of this power in the Khilafat Rosyidin government can not be distinguished clearly as in the concept of governance/administration of the country today. Even in actual practice, the three powers both the legislative authority (assulthah at tasyri'iyyah), executive (as sulthah at tanfidziyyah) and judicial (as sulthah al qada'iyyah) attached to the Caliph position.

Researcher found the birth of the concept of the Caliph who appeared in the middle of the absolutism of power personified by the king or emperor at that time, as if the reincarnation of king personality who usually is authoritarian or tyrannical figure become a king who is fair and wise called Khalifah term. Borrow a phrase from Plato, he calls the ruler was characterized as a philosopher king. Furthermore, according to Plato, until philosophers are kings, cities will never have rest from their evils [6].

Using the model of Easton (1957) and Anderson $(1974,1994)$, researcher has constructed the process and the stages of of public policy making by each caliph of four Rosyidin Khilafat using several examples of policies that they have run. There are some cases, e.g Abu Bakr policy to fight against people who refuse to give zakat (charity). This public issue demanding action immediately by $\mathrm{Abu}$ Bakr was appointed Caliph because it was being very urgent policy problems and precarious if not responded quickly. The second is the policy of the Caliph 'Umar bin al Khoththob regarding the provision of the state to the people in the form of cash, in which technical assistance allocation and distribution of it along with what criteria is used, there are differences of opinion in defining it.The third, e.g. Ustman bin Affan caliph policies related to the appointment and confirmation of Governors in their period accused that there was element of collusion and nepotism by the opposition. The fourth is Ali ibn Abi Talib policy on reformation of government management at the time of the conflict of various interest groups in society and undermined the authority of the government.

In general, the practice of Khilafat Rosyidin in policy-making that concerns the interests of the people is always preceded by a phase called policy input in the form of aspiration by the caliph and the ranks of officials, both at central and local levels as well as aspiration of the people to the Caliph either directly or indirectly. Aspiration of society indirectly to the caliph could be done either through the officials at the central level and at the regional level, 
or by officers specifically appointed by the Caliph to accept the aspirations of the community.

Through the process of ijtihad (explore in depth a law of the Qur'an and as Sunnah) and musyaawarah (deliberation) that is under consideration of ahlu syuura (assembly of consultation) [7] [8], whether requested or not requested by the caliph, the caliph then took it as a decision by consensus (ijma') or the decision was taken by the Caliph himself. Accompanying the decision-making process there are stages of policies adopted by the caliph in order to obtain the best alternatives as public policy. Which in any such policies inherent consequences that shall be accountable to the people and God.

From the reports (riwayat) obtained by researcher based the study of literature is done, getting their basic principles (contained values) and very important underlying public policy making in the government of them are: (1) principles of Equality (2) principles of Consultation, (3) Principles of Justice (4) principles of Maintaining the Human Rights (5) principles of People Benefit (Maslahat Umat).

In the context of Khilafat Rosyidin government, referring to the concept of Howlett and Ramesh (1995), so the actors of policy/policy stakeholder are composed of (formal) policymakers and all people as the receiver of policy impacts (beneficiaries), even also including animals, plants and natural surroundings. The logic underlying way of thinking, attitudes and actions of this is that the public policy implications not only in humans but also the fauna, flora and environment. This fact was very interesting because it has been 14 centuries ago preceded social and political scientists thought was only around the 1980s made the environment variable as an issue in the study of public policy.

Briefly, all of Khulafa Rosyidin stressed that all public policies are made and determined to be related governance, service to the community, setting the social order and the various activities of society and the state is in order to solely executing of obedience to Allah. These events can be justified as a form of public accountability through informal-external mechanisms i.e. accountability instruments that involved public hearings and interest groups and informal-internal mechanisms has been practiced as accountability instrument is determined by the values developed within the organization and professional ethics [9].

The basic principles underlying thought and practice of Khilafat Rosyidin in implementing public accountability e.g. is the command of Allah in the Qur'an, Surah an-Nisa verse 58 namely, 1) principle of trust (amanah), 2) principle of citizen participation and 3) principle of supervision (ihtisaab).

Their accountability can be grouped into two classifications namely accountability form of policymakers to people who have given mandate to them (public accountability) and engagement forms of giving the mandate i.e. the people -in the sense of wide-to joint controlling public policy that has been created and produced (participative accountability).

Khalifah as elected by the people it is politically accountable to the people, while transcendentally is responsible to Allah this is (transcendental accountabilit). As the officials in the central government such as ministers and heads of local government at province and regency/municipality have decision-making authority in the extension of the caliph so they must give a responsibility politically and administratively to the caliph. And, in every decision-making related to the public interest, a widespread, strategic and crucial implications, the Caliph consulted with fuqoha (jurists), professional experts and community leaders, and even heared directly from the public. This is a form of democratic accountability.

Ontologically, the thinking and practice of Khulafa Rosyidin in policy making and public accountability has found its philosophical foundation, orientation, objectives and principles and the essential values themselves. The substantial essence is that man as a creation of God has been willing to take a huge mandate, then he who holds the decision entirely in the face and solve all the problems of life. Consequently, he also accountable for any decision which he had made and set.

Epistemologically, it can be proved among others by using the process of inductive-deductive reasoning that thinking and practice of Khulafa Rosyidin in policy making and public accountability can become the theory.

In axiological perspective, the findings of thought and practice of policy making and public accountability during Khilafat Rosyidin have utility values at present although in a different context. It can be argued, among other things, the pattern of decision-making that is consistent yet dynamic, policy-making process that is participatory, common expediency into the strategic considerations, the policy orientation in the public interest, the appreciation of the leadership of integrity and professionalism, application of control procedures on policy and its implementation, responsibility on public policies that have been made, and the application of complaint mechanisms by the people. 


\section{CONCLUSION}

It found the clear evidence of thought and practices regarding policy making and public accountability in the government period of Khilafat Rosyidin. Characteristic of policy making and public accountability in their age is participatory and transcendental. The research results confirm and prove what the thesis of Robert N. Bellah has been. The empirical reality of thought and practice in policy making and public accountability in the government of Khilafat Rosyidin years 632-656 AD (10-35 Hijriyyah) can be used as concepts, theories and models of public administration. Similarly, when it is reviewed from the terms of the philosophy of science, either in the perspective of the ontological, epistemological, and axiological. As well as some approaches i.e. paradigm approach of the principles of public administration by Gulick and Urwick, Henry Fayol, comparative of the public administration of Ferrel Heady history of public administration of Dwight Waldo, the history of idea by Spicer and the approach of universalityparticularity and idiographic-nomotethic.

\section{ACKNOWLEDGMENT}

This paper is partial summary from my dissertation in doctoral program of administrative science (PDIA) at field of public administration, University of Brawijaya, Malang, Indonesia. Unlimited thank to Susilo Zauhar as promoter, Suryadi and Saad Ibrahim as the co-promoter from the State Islamic University (UIN) Malik Ibrahim. Thanks also shown to the professors at PDIA University of Brawijaya that permit me do library research using historical approach. This model is non mainstream and even still rarely done. Of course, gratitude for examiner, Bambang Supriyono, Choirul Saleh, Saleh Soeaidy, Fefta Andy Wijaya, all of them from University of Brawijaya. Special thanks to Muchlis Hamdi from the Institute of Public Administration (IPDN) and Syafiq A. Mughni is professor of history and humanities at State Islamic University of Sunan Ampel Surabaya that enriched this research findings.

\section{REFERENCES}

[1] Caiden G.H. 1982. Public Administration, Second Edition, Palisades Publisher.

[2] Haque, M.S. 1996. "Public Service Under Challenge in the Age of Privatization," Governance, Vol. 9 No. 2, , pp. 186-216

[3] Haque, M.S. 2000. "Privatization in Developing Countries : Formal Causes, Critical Reasons, and Adverse Impacts," in A. Farazmand, Eds., Privatization or Public Enterprise Reform?," Westport, Greenword Press, pp.217-238

[4] Bellah, R.N. "The Islamic Traditions and Problems of Modernization" in R.N. Bellah, Eds, Beyond Belief, New York, Harper and Row, 1976, cited from B. Effendy,"Islam and Democracy: In Search of a Viable Synthesis," Studika Islamica, Vol.2, No. 4, pp.1-21

[5] Radin, M. 1989. "The Doctrine of the Separation of Powers in Seventeenth Century Controversies," University of Pennsylvania Law Review, Juny, 1938, pp.842-866, see G.Starling, Understanding American Politics, Illinois, The Dorsey Press, 1982; J.M.G. Burns, et al., Government By the People, 13th Edition, New Jersey, Prentice Hall.

[6] Ozumba, M.C. 2011. "Plato and The Leadership Question: An Evalution of Philosopher-King within The Nigerian Political Structure," The Nigerian Academic Forum Volume 20 No. 1 April, ,pp.1-8

[7] Safi, L.M. 1991. "The Islamic State: A Conceptual Framework," The American Islamic Journal of Islamic Social Sciences, Vol.8, No.2, pp.221-234;

[8] Turabi, H. 1987. "Principles of Governance, Freedom and Responsibility in Islam," The American Islamic Journal of Islamic Social Sciences, Vol.4, No. 1.

[9] Haque, M.S. 2007. "Limits of Public Accountability Under The Reinvented State In Developing Nations," Public Administration Quaterly, Winter, pp. 429-252. 